\title{
Application of Credit Risk Management Model in Chinese Banks
}

\author{
Chen Haojie (Corresponding Author) \\ School of Economics \& Management, Xiamen University Malaysia Campus \\ Jalan Sunsuria, Bandar Sunsuria, 43900 Selangor D.E., Malaysia \\ Tel: 60-1-0899-1663Ｅ-mail: chj6869@icloud.com \\ $\mathrm{Ng}$ Sin Huei \\ School of Economics \& Management, Xiamen University Malaysia Campus \\ Jalan Sunsuria, Bandar Sunsuria, 43900 Selangor D.E., Malaysia \\ Tel: 60-3-8705-5037_E-mail: shng@xmu.edu.my \\ Lew Shian Loong \\ School of Economics \& Management, Xiamen University Malaysia Campus \\ Jalan Sunsuria, Bandar Sunsuria, 43900 Selangor D.E., Malaysia \\ Tel: 60-3-8705-5126 E-mail: shianloong.lew@xmu.edu.my
}

Received: Nov. 29, 2018 Accepted: Jan. 24, 2019 Published: June 1, 2019

doi:10.5296/ajfa.v11i1.14168 URL: https://doi.org/10.5296/ajfa.v11i1.14168

\begin{abstract}
The main objective of this paper is to perform empirical analysis and research on the KMV and Zeta models, discussing whether banks in China could adopt both models in their credit risk management practices. In order to measure credit risk, the KMV model focuses on "Expected Default Probability" (EDP) that is calculated using Black-Scholes Option Pricing Formula. On the other hand, the Zeta Model focuses on determining the probability of a company going bankrupt two years prior to the event. Previous research on risk management has shown that the primary risk the banks generally face is credit risk as an increasingly greater number of banks suffer losses because of credit issues. This paper therefore aims to add to the existing literature a strong case for the relevance of both the KMV and Zeta models to be considered in the topic of banks' credit risk management.
\end{abstract}

Keywords: KMV model, Zeta model, Expected default probability (EDP), Credit risk assessment 


\section{Ml Macrothink}

\section{Introduction}

\subsection{Background}

Since the 1990s the global economic, political and technological landscapes have experienced a wide range of dramatic transformations, which have subsequently fueled an exponential growth in credit risk. And with the inception of a floating exchange rate regime, financial markets throughout the world have since witnessed an ongoing process of deregulation. While greater financial liquidity worldwide is creating opportunities for new capital sources to thrive, the increasing complexity of credit risk is posing a host of challenges.

In China, due to the current financial system in place, credit risk has inevitably become the main factor of financial risk - which is also influenced by:

- indirect financing that dominates the financial structure,

- $\quad$ precarious relationship between banks and enterprises,

- $\quad$ vague business distinction between bank policy and commerce,

- $\quad$ inadequate financial management,

- $\quad$ weak sense of risk,

- $\quad$ lack of effective internal mechanisms and risk prevention measures, and

- $\quad$ information asymmetry between borrowers and lenders, which could potentially lead to moral hazard.

On the evidence of the above, the financial risk situation in China reflects the more obvious characteristics of the traditional form of financial risk - as opposed to what is usually seen in other developed countries.

The credit risk faced by the commercial banks in China is largely affected by bad credit assets, tendency towards concentration of credit risk and insufficient credit risk management. So, measuring credit risk has become imperative to banks. The credit risk exposure featured in the New Basel Accord mainly involves five essential aspects, namely corporate risk, bank risk, retail risk, sovereign risk and equity risk - fully affirming the important role of IRB in risk management and capital regulation. The New Basel Accord proposes an IRB method for calculating credit risk, where the data analysis time period required for parameter estimation is long, and the source and content requirements are very high. Using the PD (probability of default ), LGD (loss given default, which is amount of money a bank or other financial institution losses when a borrower defaults on a loan ), EAD (exposure at default, which is the total value a bank is exposed to when a loan defaults) and $\mathrm{M}$ (maturity is the date on which the life of a transaction or financial instrument ends, after which it must either be reviewed.), we could ascertain the risk weight of different asset situations and then determine the risk assets.

As the credit risk management model gradually develops from being qualitative to being quantitative, both the KMV model and the Zeta model will be used to discuss the feasibility of applying a credit risk management model in China. 


\section{Literature Review}

\subsection{Literature Review}

There are a number of research papers that revolve around credit risk management models, but for the purposes of our study, we shall focus our attention on those that discuss the KMV model and the Zeta model. Generally, the most common credit default model is the KMV model whereas the most accurate bankrupt probability model is the Zeta model.

Some scholars in China have researched the adaptability of KMV Model in China. Zhang Lin and Zhang Jialin (2000) as well as Wang Qiong and Chen Jinxian (2002) presented a theoretical comparison between the KMV model and the other models - pointing out that the KMV model might be more appropriate for the credit risk assessment of a public company. Xue Feng, Lu Wei, Zhao Heng Jie and Liu Jiyun (2003) used the data of China's stock market to determine the relationship function between the $\sigma_{E}$ and $\sigma_{A}$ in the actual equity market as they performed an empirical analysis based on a particular stock. Qiao Zhuo et al (2003) discussed the basic characteristics of the KMV model without any empirical evidence. On the other hand, Yi Danhui and Wu Jianmin (2004) calculated and compared the distance to default and default probability. With 30 companies in China randomly selected from the Shenzhen and Shanghai stock markets, the researchers verified the feasibility of measuring the listed company's credit risk by using distance to default.

According to Peter Crosbie (2003) the credit risk model can be summarized as follows. Credit risk can be divided into two components: single risk and portfolio risk. While single risk consists of PD, LGD and migration risk (Migration risk is a change in value caused by a deviation of the actual probability of a future default by an obligor from the expected probability of future default, adversely affecting the present value of the contract with the obligor today), portfolio risk comprises risk exposure and default correlations. In order to determine a company's credit risk default probability, we must calculate the company's value of assets, asset risk and leverage. As for the three-step method to calculate the expected default frequency of the KMV model, we must first estimate the market value of the company's assets and then calculate the volatility of those assets. And after we calculate the Distance to Default based on the volatility of the company's assets, we must eventually convert the Distance to Default to the expected default frequency using empirical distribution. As pointed out by Peter Crosbie (2003) the measurement of EDF is an effective tool in managing the credit process of institutions and continuous monitoring is the only way for detecting deterioration in credit quality. Because the EDF value is a real probability, it is widely used by institutions to measure credit risk.

Michel Crouhy, Dan Galai and Robert Mark (2000) performed a comprehensive analysis on the current credit risk models-comparing the CreditMetrics, KMV, CreditRisk+ and CreditProtfolioView models. CreditMetrics is a credit migration approach proposed by JP Morgan that accounts for the change of the company's credit quality within a time period. Meanwhile, the option pricing method or structural approach is initiated by KMV based on the asset value model originally proposed by Merton. KMV is then used to further develop the option pricing theory. As the endogenous default process in the model is compatible with the capital structure of the company, the company will suffer default when the asset value of the company is below a certain level. On the other hand, CreditRisk + is an actuarial approach 
proposed by Credit Suisse Financial Products (CSFP) to calculate default probability. Focusing on default probability using joint conditional distribution, this approach assumes that individual bonds and loans follow an exogenous Poisson process. As for the last model, Credit Portfolio View_proposed by McKinsey - is a time model using discrete time periods. Unlike the other models, Credi tPortfolio View uses macroscopic variables - such as unemployment rate, government expenditure and GDP growth - that play a vital role in the credit cycle of the economy.

According to Michel Crouhy, Dan Galai and Robert Mark (2000) both the Credit Portfolio View and KMV methods are based on the same empirical observation, with their default risk and migration probability changing over time. While the KMV method adopts microeconomic factors by using the market value of assets to measure the PD of the debtor, the Credit Portfolio View method links the PD to the probability of mitigation by using macroeconomic factors. But we still need to calibrate default data for every country and corresponding industries. And the ad-hoc procedure in adjusting the mitigation matrix is another obvious limitation. Being more practical than the simple Bayesian model though, the proposed models should perform better because the revision of transition probability depends on the accumulation of internal professional knowledge of the bank's credit department and the internal credit quality assessment of a bank's given credit portfolio. The KMV method is related to the Credit Portfolio View method since the company's market value is mostly dependent on the economic situation. Therefore, the transition matrices produced by the KMV and Credit Portfolio View methods are comparable.

Edward I. Altman and Anthony Saunders (1998) summarized the development of credit risk models in the last two decades. First, the researchers discussed the evolution of individual loans and portfolio of the loans credit risk measurement put forward by the Journal of Banking \& Finance and other well-known publications. Subsequently, the researchers presented a new mortality risk framework that could be used to measure the risk and return of loans and bonds. Offering us some hope for analyzing the risk-return structure of portfolio of debt instruments exposed to credit risk, the framework basically uses a variant Z-score model-called $Z^{\prime \prime}-$ Score model - to determine unexpected losses (the unexpected loss is the average total loss over and above the mean loss. It is calculated as a standard deviation from the mean at a certain confidence level. It is also referred to as Credit VaR.) and to assign a bond rating that is equivalent to the portfolio which each loan or bond may enter. As these scores and rating equivalents can consistently estimate expected losses, we should have a specific procedure for estimating unexpected losses if we have access to the standard deviation around the expected losses.

Edward I. Altman and Anthony Saunders (1998) also discussed the portfolio risk. The unexpected loss measure of $U A L_{p}$ in the portfolio includes the correlation between the expected loss during the sample measurement period and the unexpected loss of personal assets. So, by comparing the bond rating equivalents, we can compute the expected value of the unexpected loss by using the standard deviation of the expected loss. It has also been highlighted that in order to gain the experience and confidence in applying this fixed income portfolio technology, we must spend more time in studying additional samples. 
Stephen Kealhofer and Matthew Kurbat (2002) discussed the use of Merton's method to predict default based on debt ratings and accounting variables. Adding Moody's rating and accounting variables into Merton's method can significantly improve the viability of default prediction. It is important to note that both the Moody's ratings and the accounting variables contain default prediction information that is beyond the predictive information presented in Merton's method. However, it is still possible to show all default predictive information of Moody's ratings and accounting variables in the KMV expected default frequencies. With less incorrect default identification that is observed in other models, the expected default frequencies of KMV are more uniform. It is also worth noting that Merton's approach generally performs better than Moody's credit rating or other accounting ratios in forecasting default conditions - due to the stronger connection that Merton's approach has with accounting variables. To predict future share price, Merton's method uses historical share price information that includes information ratios such as return on asset and returns on equity. It has also been pointed out that the Merton's approach is unfair, due to the various judgements made about non-defaulting companies. Every method faces the possibility of generating too many false rejections, but this is hardly surprising since ratings and accounting ratios cannot be fully projected in the share price. There are just too many factors affecting the share price.

\section{Research Methodology}

\subsection{KMV Model Overview}

The original intention of KMV Corporation in creating the KMV model was to estimate the default probability of KMV company's borrowers. The KMV model has two stages. The first stage of the KMV model is to test the precision of the model by comparing the predicted results with the actual results. It has been observed that in most cases the KMV model can truly reflect the size of credit risk, thanks to a high sensitivity to credit risk. The second stage of KMV model is to verify the validity of the model - a subject that many famous scholars have studied before.

The pricing basis of the KMV model is modern option pricing theory, which has been a major innovation in the measurement of credit default. The KMV model has several advantages. Besides fully utilizing the information available in the capital market, the KMV model can be used to quantitatively analyze the credit risk of listed companies. Since the data used by the $\mathrm{KMV}$ model is derived from stock price information of listed companies rather than internal data that is generated within the company itself, the company's current credit situation can be accurately projected. In addition, the KMV model is based on a number of previous theoriessuch as corporate finance theory and option pricing theory-so there is a theoretical basis to support its viability.

The KMV model is more suitable for credit quality evaluation of listed companies because listed companies are more transparent about their data whereas the data of non-listed companies is less accessible. When we apply the KMV model to non-listed companies, we need to adjust the parameters of the model. And because the expected default probability is the result of comparative analysis, the accuracy of the model may be somewhat compromised. Most importantly, the KMV model assumes that the value of company assets conforms to the 
characteristics of lognormal distribution, but the value of company assets generally exhibits non-normal statistical characteristics in reality.

In short, the KMV model offers certain practical significance in calculating the probability of default.

\subsection{Zeta Model Overview}

Derived from quantitative and qualitative methods, the scoring model is a statistical method which uses a large amount of historical data to determine parameters and predict variables of default probability. LDA (Linear discriminant analysis: it is a generalization of Fisher's linear discriminant, a method used in statistics, pattern recognition and machine learning to find a linear combination of features that characterizes or separates two or more classes of objects or events. ) is one of the most commonly used statistical methods in developing scoring models. Generally, due to the choice of exogenous variables, default composition and default definition, usage of the LDA-based model is reduced. An LDA produces a scoring function, which is a linear function of variables. These variables are chosen based on their estimated contribution to the likelihood of default, the large number of qualitative characteristics and the accounting ratios. Each accounting ratio could have a big or small impact on the overall score, as determined by Altman's Z-score. Although there are many ways to calculate Z-score, the most commonly used method is the least squares method.

Proposed by Edward I. Altman, an Assistant Professor of Finance at New York University in $1968, \mathrm{Z}$-score is a quantitative analysis method used to determine the condition of the balance sheet. The lower the Z-score, the greater the probability for the company to face a financial problem in the future under normal circumstances. LDA divides the companies into two groups: performing or solvent companies and defaulting or insolvent companies. One of the challenges of such classification is whether or not we can predict which companies will be solvent and which companies will be insolvent before default. Although the approach is flawed as both solvent and insolvent companies may have similar scores, the $\mathrm{Z}$ cut-off point is used to distinguish the two groups.

Altman's Z-score is also used to estimate the possibility of financial distress, which is denoted by a weighted average of five financial ratios. As sharp decline in the company's share price is mostly caused by balance sheet issues, financial statements have a strong influence on shareholders' judgement of the company. The importance of financial ratios is therefore selfevident.

Altman' s initial research was based on financial data from manufacturing companies. Focusing on 66 companies where half had applied for bankruptcy, Altman calculated various financial indicators for those 66 companies, obtained their corresponding weights through discrete methods and selected the most important weights to build the relevant model. To validate the model, Altman calculated the Z-score for groups of bankrupt and non-bankrupt but sick companies, i.e. ST companies. Altman's goal was to ascertain how well the model could distinguish between sick companies and those that had gone bankrupt. 


\section{Macrothink}

Asian Journal of Finance \& Accounting

ISSN 1946-052X 2019, Vol. 11, No. 1

It was observed that Altman's model predicted with a 72\% accuracy a company's bankruptcy two years in advance. In the next 31 years of testing though, it was discovered that the accuracy of the model in predicting bankruptcy one year in advance had eventually increased to $80 \%-$ $90 \%$. Using the Z-score to rank a group of European companies in 2009, Graham Secker-a Morgan Stanley strategy analyst-found that companies with weaker balance sheets underperformed in most cases as those with a $\mathrm{Z}$ score of less than 1 usually underperformed by more than $4 \%$.

If the company is not listed, the market value of the company cannot be obtained directly. The Zeta model therefore has different forms for listed companies and non-listed companies. When the company is listed, the Z-score is calculated as follows:

$$
Z=1.2 X_{1}+1.4 X_{2}+3.3 X_{3}+0.6 X_{4}+1.0 X_{5}
$$

where

Z: the overall index of the Z-score model

$X_{1}$ : working capital / total assets

This suggests the company may experience shrinking liquidity when the company's liquid assets double.

$X_{2}$ : retained earnings / total assets

This ratio measures profitability, which reflects the company's age and earning power.

$X_{3}$ : earnings before interest and tax / total assets

This ratio shows the efficiency of the company in generating earnings under the same asset size.

$X_{4}$ : market value of equity / book value of total liabilities

This ratio provides a quick test of how much the company's assets can fall before the company becomes technically insolvent, i.e. when its liabilities exceed its assets.

$X_{5}:$ sales / total assets

This ratio represents asset turnover, which measures how effectively the company uses its assets to generates sales.

A great deal of factual research has shown that investors must do some serious due diligence before considering whether to invest in a company with an Altman Z-score of close to or less than 3. Companies can be classified according to their Z-score as follows:

- When the company's Z-score is more than 2.99, based on the financial figures only, the company is placed in the "Safe" zone.

- When the company's Z-score ranges from 1.80 to 2.99 , based on the financial figures only, the company is placed in the "Grey" zone. The company may or may not go bankrupt in the next two years. 


\section{Macrothink}

- When the company's Z-score is less than 1.80, based on the financial figures only, the company is placed in the "Distress" zone. There is a high probability that the company will face distress in the next two years.

When the company is not listed, the Z-score is calculated as follows:

$$
Z_{1}=0.717 X_{1}+0.847 X_{2}+3.107 X_{3}+0.42 X_{4}+0.998 X_{5}
$$

where

$\mathrm{Z}$ : the overall index of the Z-score model for private manufacturing companies

$X_{1}$ : working capital / total assets

This suggests the company may experience shrinking liquidity when the company's liquid assets double.

$X_{2}$ : retained earnings / total assets

This ratio measures profitability that reflects the company's age and earning power.

$X_{3}$ : earnings before interest and tax / total assets

This ratio shows the efficiency of the company in generating earnings under the same asset size.

$X_{4}$ : book value of equity / total liabilities

This formula uses the book value of equity, not the market value of equity.

$X_{5}$ : sales / total assets

This ratio represents asset turnover, which measures how effectively the company uses its assets to generates sales.

Non-listed companies can be classified according to their Z-score as follows:

- When the company's Z-score is more than 2.9, based on the financial figures only, the company is placed in the "Safe" zone.

- When the company's Z-score ranges from 1.23 to 2.9 , based on the financial figures only, the company is placed in the "Grey" zone. The company may or may not go bankrupt in the next two years.

- When the company's Z-score is less than 1.23 , based on the financial figures only, the company is placed in the "Distress" zone. There is a high probability that the company will face distress in the next two years.

Asset turnover changes according to the industry the company is in. Since the above formula is mainly used for companies in the manufacturing industry, we need to consider the following Altman models that provide corresponding formulas for non-manufacturing companies.

For non-manufacturing companies, the Z-score is calculated as follows: 


$$
Z_{2}=6.56 X_{1}+3.26 X_{2}+6.72 X_{3}+1.05 X_{4}
$$

where

$\mathrm{Z}$ : the overall index of the Z-score model for private manufacturing companies

$X_{1}$ : working capital / total assets

This suggests the company may experience shrinking liquidity when the company's liquid assets double.

$X_{2}$ : retained earnings / total assets

This ratio measures profitability that reflects the company's age and earning power.

$X_{3}$ : earnings before interest and tax / total assets

This ratio shows the efficiency of the company in generating earnings under the same asset size.

$X_{4}$ : book value of equity / total liabilities

This formula uses the book value of equity, not the market value of equity.

Non-manufacturing companies can be classified according to their Z-score as follows:

- When the company's Z-score is more than 2.6, based on the financial figures only, the company is placed in the "Safe" zone.

- When the company's Z-score ranges from 1.1 to 2.6, based on the financial figures only, the company is placed in the "Grey" zone. The company may or may not go bankrupt in the next two years.

- When the company's Z-score is less than 1.1, based on the financial figures only, the company is placed in the "Distress" zone. There is a high probability that the company will face distress in the next two years.

\subsection{Data Acquisition}

Since information on the bad credit records of listed companies is not disclosed publicly, we must use other means to ascertain the default probability of these companies. One way of computing the default probability is to calculate the stock yield using information on the stock price of the listed companies and then determine the default distance.

30 listed companies have been randomly selected from China's Shanghai and Shenzhen stock markets. The financial data of these companies from 1 January 2017 to 31 December 2017 is shown in Table 1. There are 10 listed companies with good performance, 10 listed companies with mediocre performance and 10 listed companies with poor performance. Through the following analysis, the feasibility of the KMV and Zeta models in reality can be ascertained.

According to the empirical analysis of a large number of default events, it has been highlighted by the KMV model that: 


\section{Macrothink}

- when the long-term debt value is less than 1.5 times the short-term debt value, the most frequent default critical point is located near the company's short-term debt value plus 0.5 times the long-term debt value, but

- when the long-term debt value is more than 1.5 times the short-term debt value, the most frequent default critical point is located near the company's 0.7 times total of short-term debt value and long-term debt value.

There are some basic assumptions in this paper.

- The default distance formula that defines the company's market value is larger than its debt value in a year, assuming that the growth rate of the company's asset value is zero.

- The stock price of a company is consistent with logarithmic normal distribution and the stock price volatility is derived from stock price logarithmically.

- $\quad$ The annual volatility of equity is computed using the stock closing price of the 252 trading days in 2017.

- The annual risk-free interest rate is fixed. The standard one-year maturity yield of China's treasury bond in 2017 and $r=2.7484 \%$ are used.

- Equity is a call option on the firm value with a strike price that is equal to the face value of debt. 
Table 1. 30 Listed Companies from Shanghai and Shenzhen Stock Markets

\begin{tabular}{|c|c|c|c|}
\hline \multicolumn{2}{|c|}{ Blue-chip Companies (Note 1) } & \multicolumn{2}{|c|}{ Ordinary Companies (Note 2) } \\
\hline Code & Industry & Code & Industry \\
\hline 600519 & Wine \& Beverage & 600000 & Banking \\
\hline 002302 & Metal \& Nonmetal & 000905 & Transportation \\
\hline 300176 & Machinery \& Equipment \& Instrument & 600549 & Metal \& Nonmetal \\
\hline 002307 & Construction Business & 603377 & Transportation \\
\hline 002081 & Decoration & 600479 & Pharmaceuticals \\
\hline 600808 & Metal \& Nonmetal & 002403 & Metal \& Nonmetal \\
\hline 000709 & Metal \& Nonmetal & 600826 & $\begin{array}{l}\text { Business Brokerage } \\
\text { \& Agency }\end{array}$ \\
\hline 601919 & Marine Traffic & 300220 & Electronics \\
\hline 601899 & Nonferrous Metal Mining & 300104 & $\begin{array}{l}\text { Information } \\
\text { Dissemination } \\
\text { Service }\end{array}$ \\
\hline 600340 & Real Estate Development & 600363 & Electronics \\
\hline \multicolumn{2}{|c|}{ ST Companies (Note 3) } & \multicolumn{2}{|c|}{ ST Companies } \\
\hline Code & Industry & Code & Industry \\
\hline 600860 & Machinery \& Equipment \& Instrument & 600608 & Metal \& Nonmetal \\
\hline 002490 & Machinery \& Equipment \& Instrument & 600403 & Coal Mining \\
\hline 000526 & Real Estate Development & 601005 & Metal \& Nonmetal \\
\hline 600696 & Real Estate Development & 000932 & Metal \& Nonmetal \\
\hline 000595 & Machinery \& Equipment \& Instrument & 000982 & $\begin{array}{l}\text { Textile \& Clothing } \\
\text { \&Fur }\end{array}$ \\
\hline
\end{tabular}

Note 1. Blue-ship Companies: They are the mature companies in the stock market that represent the stalwarts of industry-safe, stable, profitable, and long-lasting companies that represent relatively safe, low volatility investments.

Note 2. Ordinary Companies: The companies with mediocre performance.

Note 3. ST Companies: ST stand for special treatment. Under regulation of Shenzhen Stock Exchange and Shanghai Stock Exchange, in the event of financial issues or other abnormal conditions of listed companies that make investors unable to judge the future of the companies and may endanger the interest of investors, the Stock Exchange shall take special treatment on these stocks. 


\section{Ml Macrothink}

\section{Calculation and Results}

\subsection{The Calculation and Results}

\section{Equity Value Volatility $\left(\sigma_{E}\right)$}

In this paper, the volatility of equity value is derived from historical stock price data. Assuming that the stock price of listed companies conforms with logarithmic normal distribution, the volatility of equity value is expressed as:

$$
\begin{gathered}
\delta_{i}=\ln \left(\frac{S_{i}}{S_{i-1}}\right) \\
\sigma_{E}=\frac{\sqrt{\frac{1}{n-1} \sum_{i=1}^{n} \delta_{i}^{2}-\frac{1}{n(n-1)\left(\sum_{i=1}^{n} \delta_{i}\right)^{2}}}}{\sqrt{\frac{1}{n}}}
\end{gathered}
$$

where

$S_{i-1}, S_{i}$ : the stock closing price on day $i$ and $i-1$

$n$ : the trading day, where 252 days have been selected as the benchmark

$\delta_{i}$ : the log return at time $i$

$\sigma_{E}$ : the annual volatility of equity value

The results, including the volatility of equity value computed using Microsoft Excel, are shown in Table 2. 
Table 2. Average Return and Annual Equity Volatility of Selected Companies

\begin{tabular}{|c|c|c|c|c|c|}
\hline \multicolumn{3}{|c|}{ Blue-chip Stock } & \multicolumn{3}{|c|}{ Common Stock } \\
\hline Code & $\begin{array}{l}\text { Average } \\
\text { Return* }\end{array}$ & $\begin{array}{l}\text { Annual } \\
\text { Equity Volatility }\end{array}$ & Code & $\begin{array}{l}\text { Average } \\
\text { Return* }\end{array}$ & $\begin{array}{l}\text { Annual } \\
\text { Equity Volatility }\end{array}$ \\
\hline 600519 & $0.3010 \%$ & 0.2026 & 600000 & $-0.1063 \%$ & 0.2302 \\
\hline 002302 & $0.3453 \%$ & 0.6604 & 000905 & $0.0059 \%$ & 0.4636 \\
\hline 300176 & $0.5908 \%$ & 0.5288 & 600549 & $0.0639 \%$ & 0.4549 \\
\hline 002307 & $0.1180 \%$ & 0.6060 & 603377 & $0.0006 \%$ & 0.2424 \\
\hline 002081 & $0.1805 \%$ & 0.2988 & 600479 & $-0.0466 \%$ & 0.2272 \\
\hline 600808 & $0.1512 \%$ & 0.3902 & 002403 & $-0.0738 \%$ & 0.2005 \\
\hline 000709 & $0.0650 \%$ & 0.4288 & 600826 & $-0.3042 \%$ & 0.3112 \\
\hline 601919 & $0.1023 \%$ & 0.3495 & 300220 & $-0.1605 \%$ & 0.4474 \\
\hline 601899 & $0.1284 \%$ & 0.2531 & 300104 & $-0.3490 \%$ & 0.7298 \\
\hline 600340 & $0.1124 \%$ & 0.3755 & 600363 & $-0.1158 \%$ & 0.3480 \\
\hline \multicolumn{3}{|c|}{ ST Stock } & \multicolumn{3}{|c|}{ ST Stock } \\
\hline Code & $\begin{array}{l}\text { Average } \\
\text { Return (Note } \\
\text { 1) }\end{array}$ & $\begin{array}{ll}\text { Annual Equity } \\
\text { Volatility }\end{array}$ & yCode & $\begin{array}{l}\text { Average } \\
\text { Return* }\end{array}$ & $\begin{array}{l}\text { Annual } \\
\text { Volatility }\end{array}$ \\
\hline 600860 & $-0.2184 \%$ & 0.3106 & 600608 & $-0.2975 \%$ & 0.3795 \\
\hline 002490 & $-0.2840 \%$ & 0.3850 & 600403 & $-0.0819 \%$ & 0.1850 \\
\hline 000526 & $-0.0336 \%$ & 0.2347 & 601005 & $-0.0653 \%$ & 0.1994 \\
\hline 600696 & $-0.2577 \%$ & 0.3426 & 000932 & $0.1206 \%$ & 0.4118 \\
\hline 000595 & $-0.2903 \%$ & 0.4744 & 000982 & $-0.3955 \%$ & 0.3613 \\
\hline
\end{tabular}

Note 1. Average Return: It means daily average return.

DPT (Default point is the level of the market value of a company's assets, below which the firm would fail to make scheduled debt payments. The default point is firm specific and is a function of the firm's liability structure.)

According to the 2017 annual report of the selected listed companies, DPT can be derived from year-end short-term liabilities and long-term liabilities. Existing companies use a variety of debt instruments (with different maturities, coupons and so forth) so there is no unique DPT. 
"Purely empirical" rule of thumb (De Servigny/ Renault [2004] and KMV [2002]) where STD is short term debt and LTD is long term debt:

$$
\text { Default Point }= \begin{cases}S T D+0.5 L T D & \text { if } L T D / S T D<1.5 \\ S T D+\left(0.7-\frac{0.3 S T D}{L T D}\right) * L T D & \text { otherwise }\end{cases}
$$

The results are shown in Table 3 .

Table 3. DPT of Selected Companies

\begin{tabular}{|c|c|c|c|}
\hline \multicolumn{4}{|c|}{ Blue-chip Stock } \\
\hline Code & $\begin{array}{l}\text { Short-term Debt } \\
\text { (Million) }\end{array}$ & $\begin{array}{l}\text { Long-term Debt } \\
\text { (Million) }\end{array}$ & $\begin{array}{l}\text { DPT } \\
\text { (Million) }\end{array}$ \\
\hline 600519 & $38,574.92$ & 15.57 & $38,582.70$ \\
\hline 002302 & $9,489.41$ & $2,023.70$ & $10,501.26$ \\
\hline 300176 & $1,349.78$ & 191.77 & $1,445.67$ \\
\hline 002307 & $10,844.23$ & $5,439.59$ & $13,564.02$ \\
\hline 002081 & $16,022.89$ & 411.32 & $16,228.55$ \\
\hline 600808 & $28,093.36$ & $10,324.06$ & $33,255.39$ \\
\hline 000709 & $113,240.57$ & $29,248.25$ & $127,864.70$ \\
\hline 601919 & $43,491.99$ & $45,987.43$ & $66,485.71$ \\
\hline 601899 & $28,793.59$ & $22,878.83$ & $40,233.01$ \\
\hline 600340 & $228,063.69$ & $76,768.47$ & $266,447.92$ \\
\hline \multicolumn{4}{|c|}{ Common Stock } \\
\hline Code & $\begin{array}{l}\text { Short-term Debt } \\
\text { (Million) }\end{array}$ & $\begin{array}{l}\text { Long-term Debt } \\
\text { (Million) }\end{array}$ & $\begin{array}{l}\text { DPT } \\
\text { (Million) }\end{array}$ \\
\hline 000905 & $2,974.20$ & $1,578.95$ & $3,763.68$ \\
\hline 600549 & $8,200.72$ & $1,902.12$ & $9,151.78$ \\
\hline 603377 & 709.74 & 256.82 & 838.15 \\
\hline 600479 & 934.39 & 111.33 & 990.05 \\
\hline
\end{tabular}




\begin{tabular}{|c|c|c|c|}
\hline 002403 & $1,530.95$ & 562.85 & $1,812.38$ \\
\hline 600826 & 958.60 & 332.15 & $1,124.68$ \\
\hline 300220 & 99.56 & 1.31 & 100.21 \\
\hline 300104 & $14,494.25$ & $4,069.89$ & $16,529.19$ \\
\hline 600363 & $1,682.18$ & 66.09 & $1,715.23$ \\
\hline \multicolumn{4}{|c|}{ ST Stock } \\
\hline Code & $\begin{array}{l}\text { Short-term Debt } \\
\text { (Million) }\end{array}$ & $\begin{array}{l}\text { Long-term Debt } \\
\text { (Million) }\end{array}$ & $\begin{array}{l}\text { DPT } \\
\text { (Million) }\end{array}$ \\
\hline 002490 & $3,531.93$ & 759.54 & $3,911.70$ \\
\hline 000526 & $3,501.99$ & 17.64 & $3,510.81$ \\
\hline 600696 & 501.90 & 16.58 & 510.19 \\
\hline 000595 & 883.89 & 225.15 & 996.47 \\
\hline 600608 & 121.21 & 4.75 & 123.59 \\
\hline 600403 & $8,595.46$ & 846.06 & $9,018.49$ \\
\hline 601005 & $4,810.95$ & $3,397.55$ & $6,509.72$ \\
\hline 000932 & $47,920.36$ & $12,428.63$ & $54,134.67$ \\
\hline 000982 & $8,469.57$ & $1,773.63$ & $9,356.39$ \\
\hline
\end{tabular}

\section{Asset Value Volatility $\left(\sigma_{A}\right)$}

The KMV model assumes that when the asset value of a company is less than the value of its liabilities, the company will default. We can get the market value and volatility of assets through the Black-Scholes-Merton (BSM) options pricing method. The model also assumes that the company's capital structure contains only equity and short-term debt, which are recognized as cash or cash equivalents. Long-term debt is considered permanent and can be converted into preferred stock. Having made the above basic assumptions, we can use recursion based on the following formula to find out the asset value volatility:

$$
\begin{gathered}
E=V * N\left(d_{1}\right)-D * e^{-r(T-t)} * N\left(d_{2}\right) \\
d_{1}=\frac{\ln \frac{V}{D * e^{-r(T-t)}}}{\sigma_{A} * \sqrt{T-t}}+\frac{1}{2} \sigma_{A} * \sqrt{T-t} \\
d_{2}=d_{1}-\sigma_{A} * \sqrt{T-t}
\end{gathered}
$$




$$
N(d)=\int_{-\infty}^{d} \frac{1}{\sqrt{2 \pi}} e^{\frac{-1}{2} x^{2}} d_{x}
$$

The relationship between volatility of the underlying asset value $\left(\sigma_{A}\right)$ and the volatility of the equity market value $\left(\sigma_{E}\right)$ is as follows:

$$
\begin{gathered}
\sigma_{E}=N\left(d_{1}\right) *\left(\frac{V_{t}}{E_{t}}\right) * \sigma_{A} \\
\text { DefaultProbability }=1-N\left(d_{2}\right)=N\left(-d_{2}\right)
\end{gathered}
$$

where

$\mathrm{V}$ : market value of the asset

D: face value of the company's zero-coupon debt maturing at T (only liability)

$\sigma_{A}$ : the standard deviation of the assets value

$\sigma_{E}:$ the standard deviation of the equity value

$r:$ the risk-free interest rate

$N(d)$ : cumulative normal distribution function evaluated at $\mathrm{d}$

$T-t:$ the time interval (maturity)

Using Microsoft Excel, the equations are solved via the iterative method. The asset value volatility has been calculated and the results are shown in Table 4.

Table 4. Default Probability of Selected Companies

\begin{tabular}{|l|l|l|l|l|l|}
\hline \multicolumn{6}{|l|}{ Blue-chip Stock } \\
\hline Code & $\begin{array}{l}\text { Market Value } \\
\text { Assets (Million) }\end{array}$ & $\begin{array}{l}\text { Asset } \\
\text { Volatility }\end{array}$ & $d_{1}$ & $d_{2}$ & $\begin{array}{l}\text { Default } \\
\text { Probability }\end{array}$ \\
\hline 600519 & $914,768.11$ & 0.1941 & 16.5527 & 16.3586 & $1.888 \mathrm{E}-60$ \\
\hline 002302 & $32,617.70$ & 0.4478 & 2.8161 & 2.3683 & 0.0089344 \\
\hline 300176 & $15,402.80$ & 0.4792 & 5.2347 & 4.7556 & $9.894 \mathrm{E}-07$ \\
\hline 002307 & $19,913.22$ & 0.1932 & 2.2260 & 2.0328 & 0.0210386 \\
\hline 002081 & $56,724.04$ & 0.2133 & 6.1026 & 5.8893 & $1.939 \mathrm{E}-09$ \\
\hline 600808 & $65,059.21$ & 0.1908 & 3.7574 & 3.5667 & 0.0001808 \\
\hline 000709 & $169,277.27$ & 0.1049 & 2.9891 & 2.8842 & 0.0019622 \\
\hline 601919 & $135,649.89$ & 0.1782 & 4.2445 & 4.0663 & $2.388 \mathrm{E}-05$ \\
\hline 601899 & $50,804.34$ & 0.0527 & 4.9771 & 4.9244 & $4.231 \mathrm{E}-07$ \\
\hline
\end{tabular}




\begin{tabular}{|c|c|c|c|c|c|}
\hline 600340 & $359,203.70$ & 0.0970 & 3.4128 & 3.3158 & 0.0004569 \\
\hline \multicolumn{6}{|c|}{ Common Stock } \\
\hline Code & $\begin{array}{l}\text { Market Value } \\
\text { Assets (Million) }\end{array}$ & $\begin{array}{l}\text { Asset } \\
\text { Volatility }\end{array}$ & $d_{1}$ & $d_{2}$ & $\begin{array}{l}\text { Default } \\
\text { Probability }\end{array}$ \\
\hline 600000 & $5,258,054.19$ & 0.0162 & 6.2116 & 6.1955 & $2.906 \mathrm{E}-10$ \\
\hline 000905 & $9,360.42$ & 0.2772 & 3.5249 & 3.2478 & 0.0005816 \\
\hline 600549 & $37,121.61$ & 0.3427 & 4.3370 & 3.9943 & $3.244 \mathrm{E}-05$ \\
\hline 603377 & $17,629.75$ & 0.2309 & 13.4270 & 13.1961 & 4.618E-40 \\
\hline 600479 & $5,879.61$ & 0.1890 & 9.6679 & 9.4790 & $1.284 \mathrm{E}-21$ \\
\hline 002403 & $6,145.85$ & 0.1414 & 8.9007 & 8.7593 & $9.824 \mathrm{E}-19$ \\
\hline 600826 & $6,664.54$ & 0.2587 & 7.1146 & 6.8560 & $3.542 \mathrm{E}-12$ \\
\hline 300220 & $2,639.11$ & 0.4305 & 7.8778 & 7.4473 & $4.762 \mathrm{E}-14$ \\
\hline 300104 & $77,687.31$ & 0.5745 & 3.0287 & 2.4542 & 0.0070603 \\
\hline 600363 & $7,285.30$ & 0.2661 & 5.6716 & 5.4055 & $3.231 \mathrm{E}-08$ \\
\hline \multicolumn{6}{|c|}{ ST Stock } \\
\hline Code & $\begin{array}{l}\text { Market Value } \\
\text { Assets (Million) }\end{array}$ & $\begin{array}{l}\text { Asset } \\
\text { Volatility }\end{array}$ & $d_{1}$ & $d_{2}$ & $\begin{array}{l}\text { Default } \\
\text { Probability }\end{array}$ \\
\hline 600860 & $3,725.82$ & 0.2416 & 6.465176 & 6.223527 & $2.431 \mathrm{E}-10$ \\
\hline 002490 & $7,829.14$ & 0.1926 & 3.841322 & 3.648702 & 0.0001318 \\
\hline 000526 & $7,039.24$ & 0.1176 & 6.206955 & 6.089336 & $5.669 \mathrm{E}-10$ \\
\hline 600696 & $2,505.90$ & 0.2728 & 6.071256 & 5.798442 & 3.347E-09 \\
\hline 000595 & $4,978.31$ & 0.3794 & 4.50202 & 4.122615 & $1.873 \mathrm{E}-05$ \\
\hline 600608 & $2,728.17$ & 0.3624 & 8.796849 & 8.434495 & $1.663 \mathrm{E}-17$ \\
\hline 600403 & $20,207.49$ & 0.1025 & 8.194313 & 8.091863 & $2.938 \mathrm{E}-16$ \\
\hline 601005 & $25,684.72$ & 0.1488 & 9.481618 & 9.332787 & $5.156 \mathrm{E}-21$ \\
\hline 000932 & $78,591.60$ & 0.1281 & 3.187562 & 3.059412 & 0.0011089 \\
\hline 000982 & $15,674.04$ & 0.1456 & 3.80494 & 3.659331 & 0.0001264 \\
\hline
\end{tabular}

\section{Recovery Rate $\left(\rho_{t}\right)$, Expected Loss Given Default (LGD)}

According to Merton's model, at the default point of the face value of the debt, the distance to default can be calculated using the volatility of the company's assets. When the computed "Distance to Default" is high, the company is less likely to default. Since the asset value 
volatility has already been computed, the aim here is to calculate the Distance to Default in order to determine the probability of default. The following formula is used:

$$
\text { DistanceDefault }(D D)=\frac{V_{t}-D P T}{\sigma_{A} V_{t}}
$$

where

$V_{t}$ : the market value of the company's assets

$\sigma_{A}$ : the standard deviation of the asset value

The Merton model for LGD assumes that the company's value is lognormal distributed with a constant volatility and the company only has one liability, which is zero-coupon debt issue. The formula is as follows:

$$
\begin{gathered}
\text { Recovery Given Default }\left(R G D_{t}\right)=V_{t} * N\left(-d_{1}\right) / N\left(-d_{2}\right) \\
\text { Recovery Rate }\left(\rho_{t}\right)=R G D_{t} / D \\
\text { Expected Loss Given Default }\left(L G D_{t}\right)=e^{-r t} * D-R G D_{t}
\end{gathered}
$$

where

$V_{t}$ : the market value of the company's assets at time $\mathrm{t}$

$D$ : the face value of the company's zero-coupon debt maturing at T (only liability)

$r$ : the expected return on the value of the company, which uses risk-free interest rates

Using Microsoft Excel, the recovery rate, recovery given default and expected loss given default are computed. The results are shown in Table 5.

Table 5. Distance to Default and Expected Loss Given

Default of Selected Companies

\begin{tabular}{|l|l|l|l|l|}
\hline \multicolumn{5}{|l|}{ Blue-chip Stock } \\
\hline Code & $\begin{array}{l}\text { Distance } \\
\text { to Default }\end{array}$ & $\begin{array}{l}\text { Recovery Given } \\
\text { Default (Million) }\end{array}$ & $\begin{array}{l}\text { Recovery } \\
\text { Rate }\end{array}$ & $\begin{array}{l}\text { Expected Loss Given } \\
\text { Default (Million) }\end{array}$ \\
\hline 600519 & 4.9358 & $37,099.84$ & $96.1567 \%$ & $37,536.74$ \\
\hline 002302 & 1.5141 & $8,872.21$ & $84.4871 \%$ & $10,216.57$ \\
\hline 300176 & 1.8911 & $1,286.08$ & $88.9608 \%$ & $1,406.48$ \\
\hline 002307 & 1.6501 & $12,311.94$ & $90.7691 \%$ & $13,196.30$ \\
\hline 002081 & 3.3470 & $15,263.45$ & $94.0531 \%$ & $15,788.60$ \\
\hline 600808 & 2.5626 & $30,891.31$ & $92.8911 \%$ & $32,353.85$ \\
\hline 000709 & 2.3322 & $120,700.76$ & $94.3973 \%$ & $124,398.32$ \\
\hline
\end{tabular}




\begin{tabular}{|c|c|c|c|c|}
\hline 601919 & 2.8609 & $62,211.96$ & $93.5719 \%$ & $64,683.30$ \\
\hline 601899 & 3.9503 & $38,756.33$ & $96.3297 \%$ & $39,142.30$ \\
\hline 600340 & 2.6633 & $252,787.43$ & $94.8731 \%$ & $259,224.59$ \\
\hline \multicolumn{5}{|c|}{ Common Stock } \\
\hline Code & $\begin{array}{l}\text { Distance } \\
\text { to Default }\end{array}$ & $\begin{array}{l}\text { Recovery Given } \\
\text { Default (Million) }\end{array}$ & $\begin{array}{l}\text { Recovery } \\
\text { Rate }\end{array}$ & $\begin{array}{l}\text { Expected Loss Given } \\
\text { Default (Million) }\end{array}$ \\
\hline 600000 & 4.3444 & $4,744,171.22$ & $97.0474 \%$ & $4,755,985.17$ \\
\hline 000905 & 2.1573 & $3,408.85$ & $90.5725 \%$ & $3,661.64$ \\
\hline 600549 & 2.1984 & $8,262.13$ & $90.2789 \%$ & $8,903.68$ \\
\hline 603377 & 4.1250 & 801.56 & $95.6342 \%$ & 815.43 \\
\hline 600479 & 4.4011 & 944.77 & $95.4266 \%$ & 963.21 \\
\hline 002403 & 4.9864 & $1,735.90$ & $95.7804 \%$ & $1,763.24$ \\
\hline 600826 & 3.2137 & $1,055.87$ & $93.8818 \%$ & $1,094.19$ \\
\hline 300220 & 2.2349 & 92.33 & $92.1360 \%$ & 97.50 \\
\hline 300104 & 1.3702 & $13,512.09$ & $81.7468 \%$ & $16,081.09$ \\
\hline 600363 & 2.8733 & $1,594.77$ & $92.9770 \%$ & $1,668.73$ \\
\hline \multicolumn{5}{|c|}{ ST Stock } \\
\hline Code & $\begin{array}{l}\text { Distance } \\
\text { to Default }\end{array}$ & $\begin{array}{l}\text { Recovery Given } \\
\text { Default (Million) }\end{array}$ & $\begin{array}{l}\text { Recovery } \\
\text { Rate }\end{array}$ & $\begin{array}{l}\text { Expected Loss Given } \\
\text { Default (Million) }\end{array}$ \\
\hline 600860 & 3.2200 & 775.52 & $93.8114 \%$ & 804.27 \\
\hline 002490 & 2.5977 & $3,635.02$ & $92.9270 \%$ & $3,805.65$ \\
\hline 000526 & 4.2617 & $3,353.92$ & $95.5313 \%$ & $3,415.63$ \\
\hline 600696 & 2.9192 & 475.15 & $93.1316 \%$ & 496.36 \\
\hline 000595 & 2.1081 & 894.55 & $89.7720 \%$ & 969.45 \\
\hline 600608 & 2.6347 & 115.41 & $93.3809 \%$ & 120.24 \\
\hline 600403 & 5.4046 & $8,667.37$ & $96.1066 \%$ & $8,774.00$ \\
\hline 601005 & 5.0161 & $6,235.95$ & $95.7944 \%$ & $6,333.24$ \\
\hline 000932 & 2.4283 & $50,845.72$ & $93.9245 \%$ & $52,667.10$ \\
\hline 000982 & 2.7681 & $8,791.66$ & $93.9643 \%$ & $9,102.74$ \\
\hline
\end{tabular}


4.2 Zeta Model Empirical Analysis

The companies we choose are listed companies, so the Z-score is calculated as follows:

$$
Z=1.2 X_{1}+1.4 X_{2}+3.3 X_{3}+0.6 X_{4}+1.0 X_{5}
$$

We use this formula to calculate the results, which are shown in Table 6.

Table 6. Zeta Value of Selected Companies

\begin{tabular}{|c|c|c|c|c|c|c|}
\hline \multicolumn{7}{|c|}{ Blue-chip Companies } \\
\hline Code & $\mathrm{T} 1$ & $\mathrm{~T} 2$ & T3 & $\mathrm{T} 4$ & T5 & Zeta \\
\hline 600519 & 0.5473 & 0.6554 & 0.2893 & 32.4543 & 0.4536 & 22.4552 \\
\hline 002302 & 0.3020 & 0.1224 & 0.0113 & 1.9210 & 0.8187 & 2.5422 \\
\hline 300176 & 0.0740 & 0.2570 & 0.2456 & 9.0539 & 1.1087 & 7.8001 \\
\hline 002307 & 0.0386 & 0.0222 & 0.0065 & 0.3899 & 0.5024 & 0.8350 \\
\hline 002081 & 0.2895 & 0.3077 & 0.0829 & 2.4641 & 0.7450 & 3.2750 \\
\hline 600808 & -0.0557 & 0.1073 & 0.0783 & 0.7075 & 1.0144 & 1.7804 \\
\hline 000709 & -0.3208 & 0.0626 & 0.0163 & 0.2906 & 0.5731 & 0.5040 \\
\hline 601919 & -0.0304 & -0.1180 & 0.0372 & 0.7730 & 0.6792 & 1.0641 \\
\hline 601899 & -0.0013 & 0.2409 & 0.0563 & 0.2046 & 1.0586 & 1.7027 \\
\hline 600340 & 0.3204 & 0.0577 & 0.0343 & 0.3043 & 0.1587 & 0.9196 \\
\hline \multicolumn{7}{|c|}{ Ordinary Companies } \\
\hline Code & $\mathrm{T} 1$ & $\mathrm{~T} 2$ & $\mathrm{~T} 3$ & $\mathrm{~T} 4$ & $\mathrm{~T} 5$ & Zeta \\
\hline 600000 & -0.0092 & 0.0349 & 0.0115 & 0.0648 & 0.0275 & 0.1418 \\
\hline 000905 & -0.0666 & 0.2626 & 0.0289 & 1.2292 & 1.6965 & 2.8172 \\
\hline 600549 & 0.0818 & 0.1282 & 0.0641 & 2.7685 & 0.7527 & 2.9028 \\
\hline 603377 & 0.0848 & 0.1782 & 0.1043 & 17.3725 & 0.3713 & 11.4903 \\
\hline 600479 & 0.4548 & 0.2660 & 0.0902 & 4.6758 & 0.9683 & 4.9895 \\
\hline 002403 & 0.1849 & 0.1414 & 0.0418 & 2.0697 & 0.7085 & 2.5082 \\
\hline 600826 & 0.3751 & 0.3929 & 0.0766 & 4.2920 & 0.6934 & 4.5214 \\
\hline 300220 & 0.2985 & 0.0910 & -0.1467 & 25.1713 & 0.5266 & 15.6310 \\
\hline 300104 & -0.3677 & -0.6672 & -0.9727 & 3.2944 & 0.3965 & -2.2120 \\
\hline 600363 & 0.1573 & 0.2709 & 0.0554 & 3.1860 & 0.7050 & 3.3673 \\
\hline
\end{tabular}




\section{Macrothink}

Asian Journal of Finance \& Accounting ISSN 1946-052X 2019, Vol. 11, No. 1

\begin{tabular}{|l|l|l|l|l|l|l|} 
Code & T1 & T2 & T3 & T4 & T5 & Zeta \\
\hline 600860 & 0.1126 & -0.2712 & 0.0016 & 3.2187 & 0.6252 & 2.3170 \\
\hline 002490 & -0.1457 & 0.0342 & 0.0073 & 0.9128 & 0.4765 & 0.9214 \\
\hline 000526 & -0.5585 & -0.0239 & 0.0220 & 1.0025 & 0.7842 & 0.7547 \\
\hline 600696 & 0.1339 & -0.1299 & 0.0239 & 3.8492 & 0.2153 & 2.5827 \\
\hline 000595 & 0.0128 & -0.2673 & -0.0090 & 3.5903 & 0.2319 & 1.9975 \\
\hline 600608 & 0.3596 & -3.7899 & 0.2883 & 20.6771 & 2.4788 & 10.9623 \\
\hline 600403 & -0.1046 & 0.2574 & 0.0269 & 1.1851 & 0.4157 & 1.4503 \\
\hline 601005 & -0.0021 & -0.4586 & -0.2710 & 2.3360 & 0.5292 & 0.3920 \\
\hline 000932 & -0.2410 & 0.0038 & 0.0715 & 0.4053 & 1.0230 & 1.2181 \\
\hline 000982 & -0.2457 & -0.1577 & -0.0013 & 0.6168 & 0.2301 & 0.0803 \\
\hline
\end{tabular}

\section{Discussion}

\subsection{Discussion}

In order to determine the applicability of the KMV and Zeta models in China, the default probability of listed companies should be compared with the credit rating that credit rating agencies have issued them. Credit rating is an evaluation of the borrower's creditworthiness performed by credit rating agencies. Since China's economic system is now a market economy, credit rating is more important than ever. To investors credit rating is a good indicator of the company's ability to fulfil its financial obligations, so the credit ratings given by these credit rating agencies have a strong influence on investors' decision of whether to invest or not. Good credit ratings could therefore help China attract greater foreign direct investment. In China, there are five main credit rating agencies licensed by the government, which are respectively Dagong Global Credit Rating, China Cheng Xin International Credit Rating, China Lianhe Credit Rating, Golden Credit Rating International, and Shanghai Brilliance Credit Rating \& Investors Service.

According to the Credit Rating and Certification Centre of the People's Republic of China Department of Commerce Research Institute, the credit ratings of the selected listed companies can be divided into several categories. The companies' creditworthiness is mainly assessed according to the company's financial data and financial indicators, which include the company's operating turnover changes, financial debt sales ratio, financial debt degree, physical asset turnover, efficiency of investment assets, efficiency of intangible assets, current account benefit cost ratio, anomaly coefficient, residual force coefficient of payment, cost system and various asset coefficients. The corresponding credit rating is then ascertained using a proper weighting ratio. The comparison between the default probability, Z-score and credit rating of the 30 selected listed companies is shown in Table 9. 
Table 9. Comparison Between Default Probability, Z-score and Credit Rating

\begin{tabular}{|c|c|c|c|c|c|c|c|}
\hline \multicolumn{4}{|c|}{ Blue-chip Companies } & \multicolumn{4}{|c|}{ Ordinary Companies } \\
\hline Code & $\begin{array}{l}\text { Default } \\
\text { Probability }\end{array}$ & Z-score & $\begin{array}{l}\text { Credit } \\
\text { Rating }\end{array}$ & Code & $\begin{array}{l}\text { Default } \\
\text { Probability }\end{array}$ & Z-score & $\begin{array}{l}\text { Credit } \\
\text { Rating }\end{array}$ \\
\hline 600519 & $1.888 \mathrm{E}-60$ & 22.4552 & BBB & 600000 & $2.9056 \mathrm{E}-10$ & 0.1418 & $\mathrm{BBB}$ \\
\hline 002302 & 0.0089344 & 2.5422 & BBB & 000905 & 0.00058159 & 2.8172 & A \\
\hline 300176 & 9.894E-07 & 7.8001 & $\mathrm{BBB}$ & 600549 & $3.2441 \mathrm{E}-05$ & 2.9028 & A \\
\hline 002307 & 0.0210386 & 0.8350 & $\mathrm{CCC}$ & 603377 & $4.6181 \mathrm{E}-40$ & 11.4903 & BB \\
\hline 002081 & $1.939 \mathrm{E}-09$ & 3.2750 & BB & 600479 & $1.2839 \mathrm{E}-21$ & 4.9895 & AA \\
\hline 600808 & 0.0001808 & 1.7804 & BB & 002403 & $9.8236 \mathrm{E}-19$ & 2.5082 & AA \\
\hline 000709 & 0.0019622 & 0.5040 & $\mathrm{CCC}$ & 600826 & $3.5418 \mathrm{E}-12$ & 4.5214 & A \\
\hline 601919 & $2.388 \mathrm{E}-05$ & 1.0641 & BB & 300220 & 4.762E-14 & 15.6310 & BB \\
\hline 601899 & $4.231 \mathrm{E}-07$ & 1.7027 & $\mathrm{BBB}$ & 300104 & 0.00706027 & -2.2120 & $\mathrm{CC}$ \\
\hline 600340 & 0.0004569 & 0.9196 & $\mathrm{CCC}$ & 600363 & 3.2305E-08 & 3.3673 & A \\
\hline \multicolumn{4}{|c|}{ ST Companies } & \multicolumn{4}{|c|}{ ST Companies } \\
\hline Code & $\begin{array}{l}\text { Default } \\
\text { Probability }\end{array}$ & Z-score & $\begin{array}{l}\text { Credit } \\
\text { Rating }\end{array}$ & Code & $\begin{array}{l}\text { Default } \\
\text { Probability }\end{array}$ & Z-score & $\begin{array}{l}\text { Credit } \\
\text { Rating }\end{array}$ \\
\hline 600860 & $2.431 \mathrm{E}-10$ & 2.3170 & $\mathrm{CCC}$ & 600608 & 1.6632E-17 & 10.9623 & C \\
\hline 002490 & 0.0001318 & 0.9214 & $\mathrm{D}$ & 600403 & $2.938 \mathrm{E}-16$ & 1.4503 & $\mathrm{CC}$ \\
\hline 000526 & 5.669E-10 & 0.7547 & $\mathrm{D}$ & 601005 & $5.1561 \mathrm{E}-21$ & 0.3920 & $\mathrm{D}$ \\
\hline 600696 & 3.347E-09 & 2.5827 & $\mathrm{D}$ & 000932 & 0.00110886 & 1.2181 & BB \\
\hline 000595 & $1.873 \mathrm{E}-05$ & 1.9975 & $\mathrm{C}$ & 000982 & 0.00012644 & 0.0803 & $B$ \\
\hline
\end{tabular}




\subsection{Advantages and Disadvantages}

It is self-evident that KMV is of great importance to contemporary credit risk research. The $\mathrm{KMV}$ model is a default probability prediction model based on the modern option pricing theory, which is an important innovation of traditional credit risk measurement. The KMV model can take into account information in the capital market as well as quantification and analysis of credit risk for all listed companies. Since the data required by the model comes from the stock market, market information is fully utilized-leading to a better reflection of the current credit standing of listed companies. In addition, the KMV model is based on contemporary corporate finance theory and option pricing theory, so there is a strong theoretical foundation to rely on.

The KMV model has become the most important credit risk rating model in the world thanks to the strong theoretical basis and low hypothetical condition. Application of the KMV model can improve the validity of credit risk analysis of commercial banks in China, offering a useful reference to credit risk managers.

However, every model is flawed; the KMV model is no exception. First of all, the scope of application of the KMV model has certain limitations. Generally, the KMV model is more practical for listed companies than non-listed companies. Since information on listed companies is more accessible, the market value of listed companies is easier to determine. On the other hand, information on non-listed companies is not publicly disclosed. As accounting indicators are pivotal to the KMV model, it is therefore a challenge to use the model for nonlisted companies. So, we need to make some adjustments to the important variables of the KMV model when we are dealing with non-listed companies.

And the expected default probability of the companies is obtained through comparative analysis, which may reduce the accuracy of calculation to a certain extent. The KMV model also assumes that the asset value of a company is subordinated to lognormal distribution, but in actual fact the asset value of a company does not necessarily conform to this characteristic. The KMV model cannot measure portfolio risk too due to the complexity and uncertainty of the market. Consequently, we cannot get the actual default correlation between two different companies.

But the combination of Copula function theory and KMV model may help us overcome this problem for now. In short, with the gradual development and perfection of China's securities market, it will be a feasible choice for banks to use stock market data to evaluate the credit standing of listed companies.

\section{Conclusion and Recommendations}

\subsection{Conclusion}

The main purposes of this paper are as follows:

- By using the share price and financial reporting information of these listed companies, we compute the distance to default and credit default probability based on the KMV model. 
- $\quad$ By using financial statements of these listed companies, we compute the Z-score based on the Zeta Model to determine the probability of the company going bankrupt within the next two years.

- $\quad$ By comparing the default probability of the KMV model and the Z-score of the Zeta model with the credit rating of these listed companies, we ascertain whether application of credit risk management model in China's banks is feasible.

Having met the above objectives of the paper, the following conclusion can be made. Bluechip companies generally have a relatively larger Z-score and a relatively smaller default probability. The Z-score of ST companies is generally less than 1.80. For companies with a high Z-score value, the default probability of the KMV model is relatively lower in general and their credit rating is generally better, i.e. class A and B. In general, for companies with a low Z-score value, the default probability of the KMV model is relatively larger in general and their credit rating is generally poorer. But in class $\mathrm{C}$ and $\mathrm{D}$, a few companies' default probability under KMV model is very low and their Z-score is very high, i.e. 600608 and 600696. This situation may be due to insufficient sample size and list companies' wrong financial statements though they have been audited.

It is obvious that credit rating is affected by many factors, which include the credit default risk of the subject of evaluation, the ability and willingness of the economic entity to fulfil the debt and other financial obligations on time in accordance with the contract, and the technical and professional experience of the third-party credit rating agency. The process of issuing credit ratings involves a complex and structured risk assessment of credit products. The increasing complexity of investment products has only made the relationship between rating and product risk more important than ever. But the consequences of default on these complex products may be minimal since the risk of default can be dispersed. So, the default probability derived from the KMV model and the Zeta model cannot completely correspond to the entity's credit rating as these indicators are only some reference bases to help investors make an informed decision.

\subsection{Recommendations}

In the previous study, we found that the company's credit rating, Z-score and default probability do not correspond one by one. We can try to amend the specific subjects of the financial statements. By modifying these figures, we can get effective financial results. If there are opportunities in the future, I will re-analysis credit risk and consider more comprehensive factors.

It is self-evident that the measurement of credit risk is of great importance to banks. The risk management team of banks should establish the right model where benefit is balanced against risk. Banks have the responsibility to do the following actions to minimize the size of credit risk:

- Establish appropriate risk control models that are based on the actual situation, and quantitatively and qualitatively analyze its credit risk. 
- Promote the reliability of data sources in order to provide a reasonable basis for the evaluation of enterprises' credit risk.

- Maintain the independence of internal control to enhance impartiality of the evaluation results.

- Train employees regularly to strengthen their ability to review credit and to promote their awareness of the adequacy and necessity of the credit process.

\section{References}

Altman, E. I., Zhang, L., \& Yen, J. (2007, November). Corporate Financial Distress Diagnosis in Chinese. Salomon Center Working http://people.stern.nyu.edu/ealtman/ZhanglingPaper.pdf

Altman, E. I. \& Saunders, A. (1998). Credit risk measurement: Developments over the last 20 years. Journal of Banking and 21. http://socsci2.ucsd.edu/ aronatas/project/academic/science.pdf

Bookstaber, Richard M. [1987]. Option Pricing and Investment Strategies. https://www.amazon.com/pricing-investment-strategies-Richard-Bookstaber/dp/0917253817

Burgstahler, D., J. Jiambalvo, \& E. Noreen. (1989). Changes in the Probability of Bankruptcy and Equity Value. Journal of Accounting and Economics, 11, 207-24. https://doi.org/10.1016/0165-4101(89)90006-2

Crouhy, M., Galai, D., \& Mark, R. (2000). A comparative analysis of current credit risk models. Journal of Banking \& Finance, 24(1), 59-117. https://doi.org/10.1016/S0378-4266(99)000539

Crosbie, Peter J., \& Jeffrey R. Bohn (2003), Modeling Default Risk, PhD dissertation. Technical Document, Moody's KMV. https://business.illinois.edu/gpennacc/MoodysKMV.pdf

Hillegeist, S.A.; Keating E.K.; Cram, D.P. and Lundstedt, K.G. (2004). Assessing the probability of bankruptcy. Review of Accounting Studies, 5-34. https://doi.org/10.1023/B:RAST.0000013627.90884.b7

Kealhofer, S., \& Kurbat, M. (2002). The Default Prediction Power of the Merton Approach, Relative to Debt Ratings and Accounting Variables, KMV LLC, Mimeo.

$\mathrm{Mu}$, Yuan. (2007). Chinese bank's credit risk assessment, Department of Economics, University of Sterling, $\quad$ May 2007 http://citeseerx.ist.psu.edu/viewdoc/download;jsessionid=6936BCA6636D5133B152D3A5E 1BB14CC?doi=10.1.1.101.7279\&rep=rep1\&type $=$ pdf

Löffler, Gunter, \& Peter N. Posch. (2011). Credit Risk Modeling Using Excel and VBA, 2nd Ed. (John Wiley \& Sons, UK). https://www.wiley.com/enus/Credit+Risk+Modeling+using+Excel+and+VBA\%2C+2nd+Edition-p-9780470660928

Sobehart Jorge R., \& Stein, Roger M. (2000). Moody's Public firm Risk Model: a Hybrid 
Approach to Modeling Short Term Default Risk, Moody’s Investors Services

Shen Z, Zhang, \& Dan W. (2010). Global Financial Crisis's Impact on the Credit Risk of Logistics Companies: Comparative Analysis between China and US with KMV Model. 2010 International Conference on Management of e-Commerce and e-Government, 116-121 https://ieeexplore.ieee.org/document/5628642

Tudela, M., \& Young, G. (2005). A Merton-model approach to assessing the default risk of UK public companies. International Journal of Theoretical and Applied Finance, 8(06), 737-761. https://doi.org/10.1142/S0219024905003256

Vasicek, Oldrich. (2000). Comments on 'Equity Market Value and its Importance for Credit Analysis: Facts and Fiction'," KMV Corporation.

\section{Appendices}

The solution procedure of multivariate equation for Blue-chip Companies.

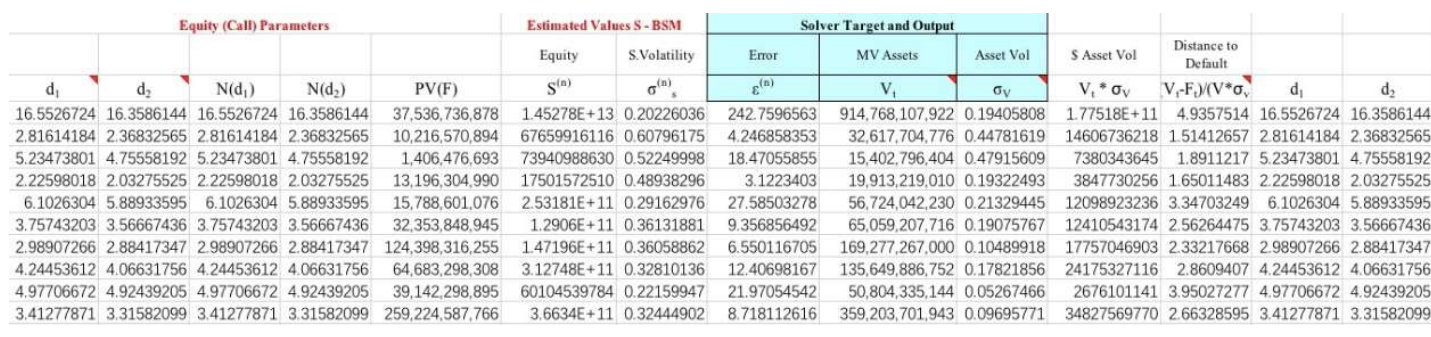

\begin{tabular}{|c|c|c|c|c|c|c|c|c|c|c|}
\hline \multicolumn{6}{|c|}{ Raw Data } & \multicolumn{3}{|c|}{ Model Input } & \multicolumn{2}{|c|}{ Initial - Starting Values } \\
\hline Code & Stock Price & Shares & ST Debt & LT Debt & Equity & $\begin{array}{c}\text { Stock } \\
\text { Volatility }\end{array}$ & USTIY & Face Value $F_{t}$ & Initial Asset Value & $\begin{array}{c}\text { Asset } \\
\text { Volatility }\end{array}$ \\
\hline Number & $P_{t}$ & $Q_{t}$ & $\mathrm{~L}_{\mathrm{t}}$ & $\mathrm{B}_{1}$ & $\mathrm{P}_{t}^{*} \mathrm{Q}_{2}$ & $\sqrt{2} 252 \sigma_{\mathrm{ts}}$ & $r_{t}$ & $\mathrm{~L}_{\mathrm{t}}+1 / 2 \mathrm{~B}_{\mathrm{t}}$ & $V_{t=V^{\prime}}^{(1)}$ & $\sigma_{\mathrm{Y}}^{\prime}=\sigma^{(1)} \mathrm{y}$ \\
\hline 600519 & 697.49 & $1,256,197,800$ & $38,574,919,400$ & $15,570,000$ & $876,185,403,522$ & 0.2026 & $2.75 \%$ & $38,582,704,400$ & $914,768,107,922$ & 0.19405808 \\
\hline 002302 & 17.52 & $1,262,354,304$ & $9,489,406,949$ & $2,023,700,844$ & $22,116,447,406$ & 0.6604 & $2.75 \%$ & $10,501,257,370$ & $32,617,704,776$ & 0.44781619 \\
\hline 300176 & 130.1 & $107,280,000$ & $1,349,783,608$ & $191,769,592$ & $13,957,128,000$ & 0.5288 & $2.75 \%$ & $1,445,668,404$ & $15,402,796,404$ & 0.47915609 \\
\hline 002307 & 11.31 & $561,379,023$ & $10,844,226,817$ & $5,439,590,885$ & $6,349,196,750$ & 0.6060 & $2.75 \%$ & $13,564,022,260$ & $19,913,219,010$ & 0.19322493 \\
\hline 002081 & 15.32 & $2,643,308,689$ & $16,022,891,319$ & $411,323,592.75$ & $40,495,489,115$ & 0.2988 & $2.75 \%$ & $16,228,553,115$ & $56,724,042,230$ & 0.21329445 \\
\hline 600808 & 4.13 & $7,700,681,186$ & $28,093,364,985$ & $10,324,058,866$ & $31,803,813,298$ & 0.3902 & $2.75 \%$ & $33,255,394,418$ & $65,059,207,716$ & 0.19075767 \\
\hline 000709 & 3.9 & $10,618,607,852$ & $113,240,573,734$ & $29,248,245,286$ & $41,412,570,623$ & 0.4288 & $2.75 \%$ & $127,864,696,377$ & $169,277,267,000$ & 0.10489918 \\
\hline 601919 & 6.77 & $10,216,274,357$ & $43,491,993,841$ & $45,987,431,030$ & $69,164,177,397$ & 0.3495 & $2.75 \%$ & $66,485,709,356$ & $135,649,886,752$ & 0.17821856 \\
\hline 601899 & 4.59 & $2,303,121,889$ & $28,793,593,015$ & $22,878,825,317$ & $10,571,329,471$ & 0.2531 & $2.75 \%$ & $40,233,005,674$ & $50,804,335,144$ & 0.05267466 \\
\hline 600340 & 31.39 & $2,954,946,709$ & $228,063,688,976$ & $76,768,471,543$ & $92,755,777,196$ & 0.3755 & $2.75 \%$ & $266,447,924,747$ & $359,203,701,943$ & 0.09695771 \\
\hline
\end{tabular}

\begin{tabular}{|c|c|c|c|c|c|c|c|}
\hline & $\begin{array}{l}\text { KMV Default } \\
\text { Probability }\end{array}$ & $\begin{array}{c}\text { Default } \\
\text { Probability }\end{array}$ & $\begin{array}{c}\text { Recovery Given } \\
\text { Default RGDt }\end{array}$ & ecovery Rate & $\begin{array}{l}\text { Expected Loss Given } \\
\text { Default LGD }\end{array}$ & European Put & \\
\hline $\mathrm{N}\left(-\mathrm{d}_{1}\right)$ & $\mathrm{N}(-\mathrm{z})$ & $\mathrm{N}\left(-\mathrm{d}_{2}\right)$ & $\mathrm{Vt} * \mathrm{~N}\left(-\mathrm{d}_{1}\right) / \mathrm{N}\left(-\mathrm{d}_{2}\right)$ & $\rho_{\mathrm{t}} \mathrm{RGD}_{\mathrm{t}} / \mathrm{F}$ & $\mathrm{e}^{-\mathrm{r} *} \mathrm{~F}-\mathrm{RGD} \mathrm{D}_{\mathrm{t}}$ & & $\mathrm{D}_{\mathrm{t}}$ \\
\hline $7.6575 E-62$ & 3.99214E-07 & $1.8881 E-60$ & $37,099,841,923$ & 0.96156665 & $37,536,736,877$ & $7.08736 \mathrm{E}-50$ & $37,536,736,878$ \\
\hline 0.00243021 & 0.064996871 & 0.0089344 & $372,210,436$ & 0.84487125 & $10,216,570,894$ & 91278932.54 & 10,125 \\
\hline $8.261 \mathrm{E}-08$ & 0.02930405 & $9.8938 \mathrm{E}-07$ & $286,078,420$ & 0.88960817 & $1,406,476,692$ & 1391.537076 & 1,406 \\
\hline 0.01300775 & 0.049459726 & 0.02103863 & $12,311,937,153$ & 0.90769072 & $13,196,304,989$ & 277632152.1 & $12,918,672,838$ \\
\hline $5.2168 \mathrm{E}-10$ & 0.000408408 & 1.9388E-09 & $15,263,454,691$ & 0.94053084 & $15,788,601,075$ & 30.61018934 & $15,788,601,045$ \\
\hline 8.58 & 0.005193914 & 0.00018077 & 30,891 & 0.92891117 & 8,944 & & $8,000,335$ \\
\hline 0.00 & 0.0098 & 0.0019 & 120,70 & 0.94 & 124,3 & 244 & 124, \\
\hline $1.0952 \mathrm{E}-05$ & 0.00211193 & $2.3881 \mathrm{E}-05$ & $62,211,955,850$ & 0.93571922 & $64,683,298,307$ & 1544696.759 & $64,681,753,611$ \\
\hline 3.2278E-07 & $3.90311 \mathrm{E}-05$ & 4.2312E-07 & $38,756,327,765$ & 0.96329685 & $39,142,298,894$ & 16561.69885 & $39,142,282,333$ \\
\hline 0.00032152 & 0.003869081 & 0.00045687 & $252,787,426,907$ & 0.94873108 & $259,224,587,765$ & 118432375.1 & $259,106,155,391$ \\
\hline
\end{tabular}

The solution procedure of multivariate equation for Ordinary Companies. 


\begin{tabular}{|c|c|c|c|c|c|c|c|c|c|c|}
\hline \multicolumn{6}{|c|}{ Raw Data } & \multicolumn{3}{|c|}{ Model Input } & \multicolumn{2}{|c|}{ Initial - Starting Values } \\
\hline Code & Stock Price & Shares & ST Debt & LT Debt & Equity & $\begin{array}{c}\text { Stock } \\
\text { Volatility }\end{array}$ & USTIY & Face Value $\mathrm{F}_{\mathrm{t}}$ & Initial Asset Value & $\begin{array}{c}\text { Asset } \\
\text { Volatility }\end{array}$ \\
\hline $\mathrm{t}$ & $P_{t}$ & $\mathrm{Q}_{\mathrm{t}}$ & $\mathrm{L}_{1}$ & $B_{t}$ & $\mathrm{P}_{\mathrm{t}}^{*} \mathrm{Q}_{\mathrm{t}}$ & $\sqrt{252 \sigma_{\mathrm{ts}}}$ & $r_{t}$ & $\mathrm{~L}_{4}+1 / 2 \mathrm{~B}_{t}$ & $V_{t=v^{\prime}}^{(1)}$ & $\sigma_{v}^{\prime}=\sigma^{(1)} v$ \\
\hline 600000 & 12.59 & $29,352,080,397$ & $4,070,768,000,000$ & $1,635,487,000,000$ & $369,542,692,198$ & 0.2302 & $2.7484 \%$ & $4,888,511,500,000$ & $5,258,054,192,198$ & 0.02 \\
\hline 000905 & 10.54 & $531,000,000$ & $2,974,202,798$ & $1,578,945,406$ & $5,596,740,000$ & 0.4636 & $2.7484 \%$ & $3,763,675,501$ & $9,360,415,501$ & 0.28 \\
\hline 600549 & 25.74 & $1,086,628,700$ & $8,200,721,054$ & $1,902,124,058$ & $27,969,822,738$ & 0.4549 & $2.7484 \%$ & $9,151,783,083$ & $37,121,605,821$ & 0.34 \\
\hline 603377 & 39.98 & $420,000,000$ & $709,739,664$ & $256,822,588$ & $16,791,600,000$ & 0.2424 & $2.7484 \%$ & $838,150,957$ & $17,629,750,957$ & 0.23 \\
\hline 600479 & 14.02 & $348,755.931$ & $934,385,381$ & $111,328,036$ & $4,889,558,153$ & 0.2272 & $2.7484 \%$ & $990,049,399$ & $5,879,607,552$ & 0.19 \\
\hline 002403 & 12.37 & $350,320,801$ & $1,530,952,418$ & $562,849,203$ & $4,333,468,308$ & 0.2005 & $2.7484 \%$ & $1,812,377,020$ & $6,145,845,328$ & 0.14 \\
\hline 600826 & 13.17 & $420,642,288$ & $958,603,722$ & $332,147,765$ & $5,539,858,933$ & 0.3112 & $2.7484 \%$ & $1,124,677,604$ & $6,664,536,537$ & 0.26 \\
\hline 300220 & 20.15 & $126,000,000$ & $99,559,055$ & $1,305,966$ & $2,538,900,000$ & 0.4474 & $2.7484 \%$ & $100,212,038$ & $2,639,112,038$ & 0.43 \\
\hline 300104 & 15.33 & $3,989,440,192$ & $14,494,250,336$ & $4,069,887,216$ & $61,158,118,143$ & 0.7298 & $2.7484 \%$ & $16.529,193,944$ & $77,687,312,087$ & 0.57 \\
\hline 600363 & 12.56 & $443,476,750$ & $1,682,184,075$ & $66,089,460$ & $5,570,067,980$ & 0.3480 & $2.7484 \%$ & $1,715,228,805$ & $7,285,296,785$ & 0.27 \\
\hline
\end{tabular}

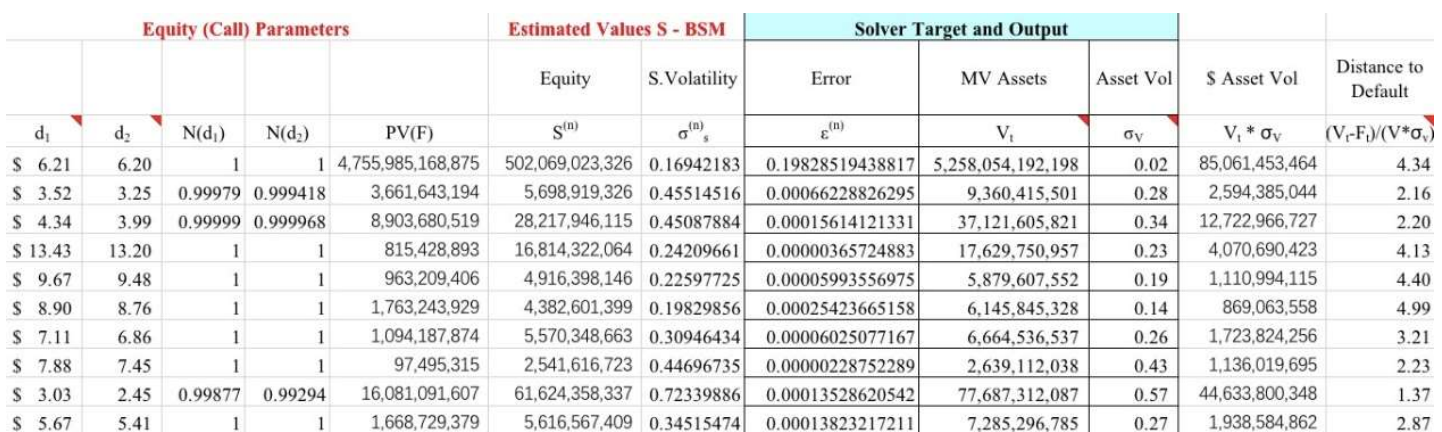

\begin{tabular}{|c|c|c|c|c|c|c|c|c|c|}
\hline & & & $\begin{array}{l}\text { KMV Default } \\
\text { Probability }\end{array}$ & Default Probability & $\begin{array}{l}\text { Recovery Given } \\
\text { Default RGDt }\end{array}$ & $\begin{array}{l}\text { Recovery } \\
\text { Rate }\end{array}$ & $\begin{array}{c}\text { Expected Loss } \\
\text { Given Default LGD }\end{array}$ & European Put & \\
\hline$d_{1}$ & $\mathrm{~d}_{2}$ & $\mathrm{~N}\left(-\mathrm{d}_{\mathrm{l}}\right)$ & $\mathrm{N}(-\mathrm{z})$ & $\mathrm{N}\left(-\mathrm{d}_{2}\right)$ & $\mathrm{Vt} * \mathrm{~N}\left(-\mathrm{d}_{1}\right) / \mathrm{N}\left(-\mathrm{d}_{2}\right)$ & $\rho_{\mathrm{l}}=\mathrm{RGD}_{\mathrm{l}} / \mathrm{F}$ & $e^{-r t} * F-R G D_{t}$ & & $\mathrm{D}_{\mathrm{t}}$ \\
\hline 6.2116 & 6.1955 & $0.0000000262 \%$ & $0.00 \%$ & $0.0000000291 \%$ & $4,744,171,222,078$ & $97.05 \%$ & $4,755,985,168,874$ & 1,382 & $4,755,985,167,493$ \\
\hline 3.5249 & 3.2478 & $0.0211800911 \%$ & $1.55 \%$ & $0.0581586760 \%$ & $3,408,854,313$ & $90.57 \%$ & $3,661,643,193$ & $2,129,563$ & $3,659,513,631$ \\
\hline 4.3370 & 3.9943 & $0.0007220464 \%$ & $1.40 \%$ & $0.0032441434 \%$ & $8,262,125,960$ & $90.28 \%$ & $8,903,680,518$ & 288,848 & $8,903,391,671$ \\
\hline 13.4270 & 13.1961 & $0.0000000000 \%$ & $0.00 \%$ & $0.0000000000 \%$ & $801,558,990$ & $95.63 \%$ & $815,428,892$ & 0 & $815,428,893$ \\
\hline 9.6679 & 9.4790 & $0.0000000000 \%$ & $0.00 \%$ & $0.0000000000 \%$ & $944,770,089$ & $95.43 \%$ & $963,209,405$ & 0 & $963,209,406$ \\
\hline 8.9007 & 8.7593 & $0.0000000000 \%$ & $0.00 \%$ & $0.0000000000 \%$ & $1,735,902,221$ & $95.78 \%$ & $1,763,243,928$ & 0 & $1,763,243,929$ \\
\hline 7.1146 & 6.8560 & $0.0000000001 \%$ & $0.07 \%$ & $0.0000000004 \%$ & $1,055,867,124$ & $93.88 \%$ & $1,094,187,873$ & 0 & $1,094,187,874$ \\
\hline 7.8778 & 7.4473 & $0.0000000000 \%$ & $1.27 \%$ & $0.0000000000 \%$ & $92,331,374$ & $92.14 \%$ & $97,495,314$ & 0 & $97,495,315$ \\
\hline 3.0287 & 2.4542 & $0.1227987676 \%$ & $8.53 \%$ & $0.7060274328 \%$ & $13,512,089,957$ & $81.75 \%$ & $16,081,091,606$ & $113,536,918$ & $15,967,554,688$ \\
\hline 5.6716 & 5.4055 & $0.0000007072 \%$ & $0.20 \%$ & $0.0000032305 \%$ & $1,594,768,789$ & $92.98 \%$ & $1,668,729,378$ & 54 & $1,668,729,325$ \\
\hline
\end{tabular}

The solution procedure of multivariate equation for ST Companies.

\begin{tabular}{|c|c|c|c|c|c|c|c|c|c|c|}
\hline \multicolumn{6}{|c|}{ Raw Data } & \multicolumn{3}{|c|}{ Model Input } & \multicolumn{2}{|c|}{ Initial - Starting Values } \\
\hline Code & Stock Price & Shares & ST Debt & LT Debt & Equity & $\begin{array}{c}\text { Stock } \\
\text { Volatility }\end{array}$ & UST1Y & Face Value $F_{t}$ & $\begin{array}{c}\text { Initial Asset } \\
\text { Value }\end{array}$ & $\begin{array}{c}\text { Asset } \\
\text { Volatility }\end{array}$ \\
\hline Number & $P_{t}$ & $Q_{t}$ & $L_{t}$ & $\mathrm{~B}_{\mathrm{t}}$ & $\mathrm{P}_{\mathrm{t}}^{*} \mathrm{Q}_{\mathrm{t}}$ & $\sqrt{ } 252 \sigma_{\mathrm{ts}}$ & $r_{t}$ & $\mathrm{~L}_{\mathrm{t}}+1 / 2 \mathrm{~B}_{\mathrm{t}}$ & $\mathrm{V}_{\mathrm{t}=\mathrm{v}^{\prime}}^{(1)}$ & $\sigma_{\mathrm{V}}^{\prime}=\sigma^{(1)} \mathrm{V}$ \\
\hline 600860 & 6.87 & $422,000,000$ & $52,644,278$ & $48,075,447$ & $899,140,000$ & 0.31055468 & 2.74 & $826,682,001$ & $3,725,822,001$ & 24164909 \\
\hline 002490 & 4.91 & $797,848,400$ & $3,531,929,198$ & $759,540,675$ & $3,917,435,644$ & 38495789 & $2.7484 \%$ & 3,911 & $7,829,135,180$ & 19261997 \\
\hline 000526 & 36.68 & 95,107 & $3,501,987,410$ & $17,636,793$ & $3,528,436,525$ & 3465 & $2.7484 \%$ & 807 & $7,039,242,332$ & 0.11761904 \\
\hline 600696 & 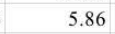 & $0,565,550$ &, 192 & 48 & 123 & 0.34255648 & $2.7484 \%$ & 7,715 & $2,505,901,838$ & 0.27281388 \\
\hline 000595 & 5.21 & $64,269,250$ &, 791 & $225,151,241$ & $3,981,842,793$ & 0.4743 & $2.7484 \%$ & 412 & $4,978,308,204$ & 0.37940504 \\
\hline 600608 & 7.92 & $328,861,441$ & $121,210,542$ & $4,754,040$ & $2,604,582,613$ & 0.37954739 & $2.7484 \%$ & $123,587,562$ & $2,728,170,174$ & 0.36235369 \\
\hline 600403 & 4.68 & $2,390,812,402$ & $, 595,458,947$ & $46,063,343$ & $11,189,002,041$ & 0.18502637 & $2.7484 \%$ & $9,018,490,618$ & $20,207,492,660$ & 0.10245014 \\
\hline 601005 & 2.15 & $8,918,602,000$ & $4,810,947,000$ & $3,397,548,000$ & $19,174,994,300$ & 0.19935767 & $2.7484 \%$ & $6,509,721,000$ & $25,684,715,300$ & 0.14883101 \\
\hline 000932 & 8.11 & $3,015,650,025$ & $47,920,357,605$ & $12,428,633,063$ & $24,456,921,703$ & 0.41180518 & $2.7484 \%$ & $54,134,674,137$ & $78,591,595,840$ & 0.12814967 \\
\hline 0982 & 3.5 & $805,043,279$ & $8,469,572,905$ & $, 773,626,618$ & $, 317,651,477$ & 0.36125333 & $.7484 \%$ & $9,356,386,213$ & $15,674,037,690$ & 0.145608 \\
\hline
\end{tabular}




\begin{tabular}{|c|c|c|c|c|c|c|c|c|c|c|}
\hline \multicolumn{5}{|c|}{ Equity (Call) Parameters } & \multicolumn{2}{|c|}{ Estimated Values S - BSM } & \multicolumn{3}{|c|}{ Solver Target and Output } & \multirow[b]{2}{*}{ Asset Vol } \\
\hline & & & & & Equity & S.Volatility & Error & MV Assets & Asset Vol & \\
\hline$d_{1}$ & & $\mathrm{~N}\left(\mathrm{~d}_{1}\right)$ & $\mathrm{N}\left(\mathrm{d}_{2}\right)$ & $\mathrm{PV}(\mathrm{F})$ & $S^{(n)}$ & $\sigma^{(n)}{ }_{s}$ & $\varepsilon^{(\mathrm{n})}$ & $V_{t}$ & $\sigma_{\mathrm{V}}$ & $\mathrm{V}_{\mathrm{t}} * \sigma_{\mathrm{V}}$ \\
\hline 6.46517567 & 6.22352658 & 6.46517567 & 6.22352658 & $804,270,858$ & 19082692701 & 0.30503378 & 31.1611704 & $3,725,822,001$ & 0.24164909 & 900341496.8 \\
\hline 3.84132212 & 3.64870215 & 3.84132212 & 3.64870215 & $3,805,654,334$ & 16188530964 & 0.35783958 & 9.817084 & $7,829,135,180$ & 0.19261997 & 1508047755 \\
\hline 6.20695485 & 6.08933581 & 6.20695485 & 6.08933581 & $3,415,628,735$ & 22893348974 & 0.22447749 & 30.1226764 & $7,039,242,332$ & 0.11761904 & 827948929.4 \\
\hline 6.07125609 & 5.7984422 & 6.07125609 & 5.7984422 & $496,356,653$ & 12335876419 & 0.33646436 & 26.844985 & $2,505,901,838$ & 0.27281388 & 683644809.5 \\
\hline 4.5020199 & 4.12261486 & 4.5020199 & 4.12261486 & $969,451,482$ & 18415767533 & 0.46174528 & 13.1408663 & $4,978,308,204$ & 0.37940504 & 1888795242 \\
\hline 8.79684878 & 8.43449509 & 8.79684878 & 8.43449509 & $120,237,134$ & 22985160958 & 0.37834127 & 61.2289491 & $2,728,170,174$ & 0.36235369 & 988562521.2 \\
\hline 8.19431305 & 8.09186291 & 8.19431305 & 8.09186291 & $8,774,001,580$ & 94588502778 & 0.17934909 & 55.5586334 & $20,207,492,660$ & 0.10245014 & 2070260385 \\
\hline 9.48161828 & 9.33278727 & 9.48161828 & 9.33278727 & $6,333,244,082$ & $1.84426 \mathrm{E}+11$ & 0.19653 & 74.2708004 & $25,684,715,300$ & 0.14883101 & 3822682094 \\
\hline 3.18756213 & 3.05941246 & 3.18756213 & 3.05941246 & $52,667,096,583$ & 89385223080 & 0.35915881 & 7.0643211 & $78,591,595,840$ & 0.12814967 & 10071486997 \\
\hline 3.80493989 & 3.65933142 & 3.80493989 & 3.65933142 & $9,102,736,910$ & 26328840051 & 0.32982502 & 10.0406525 & $15,674,037,690$ & 0.14560847 & 2282272662 \\
\hline
\end{tabular}

\begin{tabular}{|c|c|c|c|c|c|c|c|c|c|c|}
\hline $\begin{array}{l}\text { Distance to } \\
\text { Default }\end{array}$ & & & & $\begin{array}{c}\text { KMV Default } \\
\text { Probability }\end{array}$ & $\begin{array}{c}\text { Default } \\
\text { Probability }\end{array}$ & $\begin{array}{c}\text { Recovery Given } \\
\text { Default RGDt }\end{array}$ & $\begin{array}{c}\text { Recovery } \\
\text { Rate }\end{array}$ & $\begin{array}{c}\text { Expected Loss } \\
\text { Given Default } \\
\text { LGD }_{\mathrm{t}}\end{array}$ & European Put & \\
\hline$\left(V_{t}-F_{t}\right) /\left(V^{*} \sigma_{v}\right)$ & $d_{1}$ & $\mathrm{~d}_{2}$ & $\mathrm{~N}\left(-\mathrm{d}_{1}\right)$ & $N(-z)$ & $\mathrm{N}\left(-\mathrm{d}_{2}\right)$ & $\mathrm{Vt}^{*} \mathrm{~N}\left(-\mathrm{d}_{1}\right) \mathrm{N}\left(-\mathrm{d}_{2}\right)$ & $\rho_{t}=R_{G D} / F$ & $e^{-t t} * F-R G D_{t}$ & & $\mathrm{D}_{\mathrm{t}}$ \\
\hline 3.22004485 & 6.46517567 & 6.22352658 & $5.0591 \mathrm{E}-11$ & 0.00064085 & $2.4305 \mathrm{E}-10$ & $775,522,013$ & 0.93811407 & $804,270,857$ & 0.195479 & $804,270,857$ \\
\hline 2.59768673 & 3.84132212 & 3.64870215 & $6.1187 \mathrm{E}-05$ & 0.0046927 & 0.00013178 & $3,635,024,788$ & 0.92926994 & $3,805,654,333$ & 501525.239 & $3,805,152,809$ \\
\hline 4.26165963 & 6.20695485 & 6.08933581 & $2.7011 \mathrm{E}-10$ & $1.0146 \mathrm{E}-05$ & $5.669 \mathrm{E}-10$ & $3,353,919,810$ & 0.95531339 & $3,415,628,734$ & 1.93632121 & $3,415,628,733$ \\
\hline 2.91922661 & 6.07125609 & 5.7984422 & $6.3457 \mathrm{E}-10$ & 0.00175451 & $3.3467 \mathrm{E}-09$ & $475,145,943$ & 0.93131592 & $496,356,652$ & 1.66115094 & $496,356,652$ \\
\hline 2.10813894 & 4.5020199 & 4.12261486 & $3.3655 \mathrm{E}-06$ & 0.01750949 & $1.873 \mathrm{E}-05$ & $894,546,504$ & 0.89771957 & $969,451,481$ & 18157.6189 & $969,433,325$ \\
\hline 2.63471713 & 8.79684878 & 8.43449509 & $7.0356 \mathrm{E}-19$ & 0.00421037 & $1.6632 \mathrm{E}-17$ & $115,407,190$ & 0.9338091 & $120,237,133$ & $1.9998 \mathrm{E}-09$ & $120,237,134$ \\
\hline 5.40463515 & 8.19431305 & 8.09186291 & $1.2601 \mathrm{E}-16$ & $3.247 \mathrm{E}-08$ & $2.938 \mathrm{E}-16$ & $8,667,368,774$ & 0.96106645 & $8,774,001,579$ & $2.5778 \mathrm{E}-06$ & $8,774,001,580$ \\
\hline 5.01611011 & 9.48161828 & 9.33278727 & $1.2518 \mathrm{E}-21$ & $2.6364 \mathrm{E}-07$ & $5.1561 \mathrm{E}-21$ & $6,235,945,580$ & 0.9579436 & $6,333,244,082$ & $3.2655 \mathrm{E}-11$ & $6,333,244,082$ \\
\hline 2.42833275 & 3.18756213 & 3.05941246 & 0.00071739 & 0.00758421 & 0.00110886 & $50,845,718,943$ & 0.93924494 & $52,667,096,582$ & 58400328.4 & $52,608,696,255$ \\
\hline 2.76814054 & 3.80493989 & 3.65933142 & $7.0919 \mathrm{E}-05$ & 0.00281886 & 0.00012644 & $8,791,662,679$ & 0.93964299 & $9,102,736,909$ & 1150923.35 & $9,101,585,986$ \\
\hline
\end{tabular}

